\title{
A serological investigation for Feline Panleukopenia Virus in Cats in Afyonkarahisar
}

\author{
Sibel GÜR ${ }^{1 *}$, Keziban AVDATEK ${ }^{2}$ \\ 1 Afyon Kocatepe University, Faculty of Veterinary Medicine, Department of Virology, 03200, Afyonkarabisar / TURKEY \\ 2 Afyonkarahisar Directorate of Provincial Food Agriculture and Livestock, Afyonkarahisar, 03100 / TURKEY \\ Corresponding author e-mail: sibelgur@aku.edu.tr \\ \# The study was granted by Afyon Kocatepe University, Scientific Research Projects Commission with number 06.VF.03.
}

\begin{abstract}
Feline Panleukopenia Virus (FPLV) infection was one of the most important viral infections of cats with worldwide dissemination. It's presence was reported in many domestic and wild carnivor species. In this study, blood samples were collected from 151 clinically healthy stray cats in the aged among 3 months and 6 years old from five diffrent localisation at the Afyonkarahisar province, Turkey. The obtained samples were controlled using indirect FPLV ELISA test kit and 24 $(15.9 \%)$ samples were found to be antibody positive. Of the sampling performed district, all of the samples collected from İhsaniye and Sandiklı were detected as negative and 27.7\% (5/18) and 16.6\% (1/6) values were found to be in Bolvadin and İscehisar, respectively. The most of the samples was obtained from center of the province, out of 115 cats, 18 $(15.6 \%)$ were determined as positive for FPLV specific antibody. Even though presence of FPV infection has been known for a long time, this is the first serological report in Turkey.
\end{abstract}

Key Words: ELISA, Feline, Parvovirus

\section{Afyonkarahisar'da Kedilerde Feline Panleukopenia Virusunun Serolojik Olarak Araştırılması}

ÖZ

Feline Panleukopenia Virus (FPLV) enfeksiyonu kedilerin dünya çapında yaygınlığı olan en önemli viral enfeksiyonlarından biridir. Varlığı birçok evcil ve vahşi karnivor türünde bildirilmiştir. Bu çalışmada Afyonkararahisar ilinde 5 farklı noktadan, yaşları 3 ay ile 6 yaş arasında değişen klinik olarak sağlıklı toplam 151 sokak kedisinden kan örnekleri toplandı. Elde edilen örnekler indirekt FPLV ELISA test kiti kullanılarak kontrol edildi ve 24 örneğin (\%15.9) antikor pozitif olduğu tespit edildi. Örnekleme yapılan ilçelerden İhsaniye ve Sandıklı'dan elde edilen tüm örnekler negatif idi ve Bolvadin ve İscehisar'dan toplanan örneklerde ise sırasıly \%27.7 (5/18) ve \%16.6 (1/6) oranlarında pozitiflik belirlendi. Örneklerin büyük çoğunluğu il merkezinden sağlanmış olup, 115 kedinin 18'inin (\%15.6) FPLV spesifik antikor pozitif olduğu görülmüştür. Enfeksiyonun varlığ1 uzun süredir bilinmesine rağmen, Türkiye’deki ilk serolojik bildirim bu çalışma ile ortaya konulmuştur.

Anahtar Kelimeler: ELISA, Kedi, Parvovirus

To cite this article: Gür S, Avdatek K. A serological investigation for Feline Panleukopenia Virus in Cats in Afyonkarahisar. Kocatepe Vet J. 2016; 9(3):165-170. 


\section{INTRODUCTION}

Feline Panleukopenia virus (FPLV) is higly contagious acute disease characterised with fever, leukopenia, diarrhea, dehydration in cats. Genome is a linear single stranded DNA belonging to the Parvovirus genus of Parvoviridae family (Steinel et al. 2000). Parvovirus capsids are non-enveloped and icosahedral symmetry.

FPLV is an important pathogen of felids (Truyen and Parrish 1992) and has been seen worldwide in cats since its emergence in the 1928 (Verge and Christofoni 1928). The first isolation of the FPLV was accomplished from a leopard (Panthera pardus) (Johnson 1964). Many species of the families Mustelidae, Procyonidae and Viverridae are susceptible to the virus (Barker et al. 1983). Seropositivity detected species are wolf (Canis lupus) (Goyal et al. 1986), red fox (Vulpes vulpes) (Barker et al. 1983), blue fox (Alopex lagopus) (Veijaleinen 1986), grey fox (Urocyon cinereoargenteus), coyote (Canis latrans) (Davidson et al. 1992), mink (Macpherson 1956) and jackal (Canis aureus, C. Mesomelas, C. Adustus) (Alexander et al. 1994). Clinical disorders were also observed in racoon (Procyon lotor) (Waller, 1940) and lion (Panthera leo) (Studdert et al. 1973).

The virus is excreted in high concentration in faeces, urine, saliva and vomit. It is resistant to many chemicals and has a wide temperature tolerance. Transmission usually occurs through direct contact between susceptible and infected cats but can also occur indirectly through contact with contaminated objects. Symptoms onset suddenly, fever, loss of appetite, gastrointestinal disorders, dehydration, leukopenia are general findings and prognosis is more severe especially in newborns and young animals. Mortality and morbidity rates are very high (Baker et al. 1983, Steinel et al. 2001). A variant virus, Canine Parvovirus (CPV) was emerged in 1978 in dogs (Appel et al. 1979), but a retrospective study proved previous presence of the virus (Koptopoulos et al. 1986). Sequences of the FPLV and CPV were found to be $98 \%$ identical (Martyn et al. 1990). Cats can also infected by CPV (2a, 2b and 2c) (Mochizuki et al. 1996, Decaro et al. 2010, Clegg et al. 2012). FPV and CPV strains can not be discriminated serologically, antibodies gives cross-reaction (Nakamura et al. 2001).

Presence of the infection has been known clinically in Turkey for a long time but scientific report on this issue is quite limited. There is no info on prevalence. According to a genetic analysis of CPV VP2 gene, CPV $2 a-2 c$ and FPLV viruses were isolated from from clical cases in Ankara (Muz et al. 2012).

Aim of this study is to investigate the FPLV infection as serologically in Afyonkarahisar provice and to obtain the first datas for presence and prevalence in unowned cats.

\section{MATERIAL AND METHODS}

\section{Sampled Animals}

In this study, blood samples were collected from free-ranges cats in central and boroughs of Afyonkarahisar. Animals were accepted as nonvaccinated because of they are unowned and there is no routine health applies for stray cats under shelter conditions. Sampling was performed randomly. Total of 151 samples was collected; 71 male, 79 female and sex was not noted 1 cat (table 1). Big majority of the samples was obtained from city center (115), rest of them collected from boroughs (Bolvadin 18, İhsaniye 9, İscehisar 6 and Sandiklı 3) (table 1). Age of the animals was between 3 month old and 6 years old. Age distribution was given in table 2 .

All of the cats were clinical healthy during sampling, however low body weight was observed in some of them probably due to malnutrition.

Blood samples were taken from Vena Cephalica into vacutainer serum tubes and transferred to the lab in cool-chain. After centrifugation in 3000rpm for 10 min., serum fraction was transferred to the stock tubes and kept in $-80^{\circ} \mathrm{C}$, untill to the test.

\section{Method \\ Serological Test}

The obtained sera samples were tested for FPLV virus specific antibodies using an indirect ELISA test (EVL, Netherlands). The test was performed according to producer's instructions. Plates were read in $450 \mathrm{~nm}$, and each one OD values were calculated.

\section{RESULTS}

As a result of the ELISA, out of 151 samples, 24 cat $(15.9 \%)$ was found to be seropositive for FPLV specific Abs. Positivity was found to be $15.6 \%$ $(18 / 115)$ in the center. Out of 4 borougs, $\mathrm{Ab}$ detected in only two as $16.6 \%$ and $27.7 \%$ (table 1 ).

Table 1: Sampled animals and FPLV serological test results

Tablo 1: Örneklenen hayvanlar ve FPLV serolojik test sonuçları

\begin{tabular}{c|ccc}
\hline Locations & $\begin{array}{c}\text { Animal } \\
\text { Number }\end{array}$ & $\begin{array}{c}\text { FPLV } \\
\mathrm{Ab}(+)\end{array}$ & $\begin{array}{c}\text { FPLV } \\
(\%)\end{array}$ \\
\hline Central & 115 & 18 & 15.6 \\
Bolvadin* & 18 & 5 & 27.7 \\
İscehisar* & 6 & 1 & 16.6 \\
İhsaniye* & 9 & - & - \\
Sand1kl1* & 3 & - & - \\
\hline Total & 151 & 24 & 15.9 \\
\hline *; Boroughs of the Afyonkarahisar
\end{tabular}


Seropositivity distribution according to ages was given in table 2. The highest proportion was found to be in the youngest group (25\%). Ages of these kittens were 3-6 month old and it was considered as a result of natural infection other than maternal positivity. Second highest rate was observed in around two years old cats $(22.2 \%, 8 / 36)$. In the other groups, determined ratios was very close to each other (12.1-12.7\%). All of the samples were negative at the age 5-6 yr.

Table 2: Age distribution of sampled cats and seropositivity rates

Tablo 2: Örneklenen kedilerin yaş dağıllımı ve pozitiflik oranlar1

\begin{tabular}{c|c|c|c}
\hline Age & $\begin{array}{c}\text { Animal } \\
\text { Number }\end{array}$ & $\begin{array}{c}\text { FPLV } \\
\mathrm{Ab}(+)\end{array}$ & $\begin{array}{c}\text { FPLV } \\
(\%)\end{array}$ \\
\hline 3-6 mo. & 16 & 4 & 25 \\
$6 \mathrm{mo}-1 \mathrm{yr}$ & 55 & 7 & 12.7 \\
$2 \mathrm{yr}$ & 36 & 8 & 22.2 \\
$3 \mathrm{yr}$ & 33 & 4 & 12.1 \\
$4 \mathrm{yr}$ & 8 & 1 & 12.5 \\
$5 \mathrm{yr}$ & 1 & - & - \\
$6 \mathrm{yr}$ & 2 & - & - \\
\hline Total & 151 & 24 & 15.9 \\
\hline
\end{tabular}

Gender distribution of positivity was found to be almost equal, the ratio was $16.5 \%(13 / 79)$ in female and $15.5 \%(11 / 71)$ in male (table 3$)$.

Table 3: Gender distribution of cats and seropositivity rates

Tablo 3: Kedilerin cinsiyet dağılımı ve pozitiflik oranlar1

\begin{tabular}{c|c|c|c}
\hline Sex & $\begin{array}{c}\text { Animal } \\
\text { Number }\end{array}$ & $\begin{array}{c}\text { FPLV } \\
\mathrm{Ab}(+)\end{array}$ & $\begin{array}{c}\text { FPLV } \\
(\%)\end{array}$ \\
\hline Male & 71 & 11 & 15.5 \\
Female & 79 & 13 & 16.5 \\
Not & 1 & - & - \\
Defined & & & \\
\hline Total & 151 & 24 & 15.9 \\
\hline
\end{tabular}

\section{DISCUSSION}

FPLV infection is widespread in many parts of the world in wild felidae species and domestic cats. Serological investigations shows that seropositivity can be reach to $53.6 \%$ in cat populations (Nakamura et al. 1999, Lickey et al. 2005).

The samples were collected from 5 different localisations in this study. Specific antibody presence was found to be in city center and two boroughts between $15.6 \%$ and $27.7 \%$. Average proportion in these tree localisation was $17.3 \%(24 / 139)$. The samples from other two localisations were totally negative, but it is not easy to conclude to FPLV free status due to less number of evaluated cats.
On the looking of age distribution; out of 16 samples at the age of 3-6 month old, $4(25 \%)$ was found to be seropositive. Considering Maternally Derived Antibody (MDA) level of duration, it is possible to say that results reflexs the natural infection. We know that kittens that borned from immune mothers can be protected untill 10 week (Reif 1976, Scott 1997). There were 55 cats at the age of 6 month and 1 year old, ratio was $12.7 \%(7 / 55)$. The highest value was detected in the cats between 1 and 2 years old as $22.2 \%(8 / 36)$. The other 3 and 4 year old cats have similar proportion, $12.1 \%$ and $12.5 \%$ respectively. There were only 3 cats in 5 and 6 years old, no $\mathrm{Ab}$ was determined in them (table 2). There is no noteworthy difference in the aspect of sex and infection rates (Reif 1976), similar finding was observed in this study.

Newborn kittens were not sampled to refrain MDA presence possibility. According to behavioural characteristics of mother cats, it can be said that kittens are well protected and it is not easy to meet newborns in open space. Additionally to sick ones also. By the way, frequency of the infection in infants was unknown. However, obtained serologic data in this study showed that, nearly one of the six cats have been exposed to the virus and survived. There is positive correlation between age and sensitivity to FPLV. Mortality can be reach up to $80 \%$ in kitten. However, this ratio reduces to nearly $20 \%$ in the following ages (Legeay 1988).

CPV has been accepted as variant of FPLV via direct mutation or mutated vaccine strain (Truyen, 1999). Important changes had been determined in last tree decade in parvovirus capsid proteins. The mostly supported explanation is mediator role of wild species (Truyen et al. 1998). Comparing canine and feline viruses, mutation rate is higher in CPV. First isolated CPV2 was not pathogenic for felines but following year's isolates have wider host spectrum. Morover, it is thought that the vaccines that produced using new antigenic variants could be more protective (Ikeda et al. 2002, Truyen 2006).

FPLV can repicate in dog derived cell lines but as invitro, replication is ratherly limited (Chang et al. 1992, Truyen and Parrish 1992). Vice-versa situation is described for CPV2 (Parrish 1991, Truyen and Parrish 1992). Later on, CPV subtypes was isolated from healthy and sick cats (Ikeda et al. 2000). Live modified live FPLV vaccines were applied in dogs and immunisation was found to be succesfull (Carmichael 2005). Some strain of FPLV vaccines can protect cats also from CPV-2b (Chalmers et al. 1999).

Beside clinical or subclinically infected cats, dogs could be another possible source of the feline parvovirus (FPV) in the field conditions. CPV is not well investigated scientifically in Turkey, but it's presence and prevalency are well-known. Considering cross reaction of antibodies and 
similarity in clinical manifestations of the CPV and FPLV, we can not say exact causative strains in the absence of virological examination in this study. In only one research, CPV 2a, 2c and FPL viruses was reported in Ankara (Muz et al. 2012). Rather than FPLV, feline parvovirus infections (FPV) term could be more suitable description in this case.

The agent is resistant to environmental conditions and many disinfectants. The most effective substances are chlorite solutions. Infected animals spreads the virus in high titer, parvoviruses can account among environmental pollutant viruses. Morbidity in a susceptible population often approach to $100 \%$. One of the most important study on Parvovirus transmission modelling and effectiveness of FPLV on feral cat population was carried out in sub-Antarctic Marion island. Five cats were introduced to the island to help eradicate a mouse problem in 1949 (Bester and Skinner 1991). In 1977, cat population was estimated as 3.405 , and some bird species gone under big risk and one specie become extinct from the island. In 1977, 96 cats were captured using traps and a virulent strain of feline parvovirus inoculated intranasally to create an epidemic as a biological control measurement (Howell 1984). The virus was disseminated between cats via direct-indirect contact and environmetally in a short time and number of cats was reduced to 4 from $9 \mathrm{sq} / \mathrm{m}^{2}$. Despite sharp decrease, some animals become immune and survived (Bester and Skinner 1991). By 1982, there were 615 remaining (Van Rensburg et al. 1987), after that cats killed with different methods like trapping, hunting and poisoning. The whole cat population was eradicated in 1991 (Bester and Skinner 1991) .

Average life expectancy is nearly $12-15$ years in cats, however, some cats may attain the age of 21 years or more. This life span is nearly only 5-6 years in the stray cats due to infection, accidents, fight with other animals, unbalanced nutritions, food poisoning, lack of medical care and vaccination etc. Actually, indoor cats can not be stood away from the infection. Scientific reports display indifferences in incidence according to gender, breeding styles, single or multiple households, vaccinated or not (Blanco et al. 2009).

Immunisation and hygene are the most important preventive measurements. Feline panleukopenia is now diagnosed infrequently by veterinarians, presumably as a consequence of widespread vaccine usage. The infection rates remain high in some unvaccinated cat populations. In fact, vaccination against FPLV does not always adequately proctective. In germany, several outbreaks were reported in 2008/2009 (Hoffmann et al. 2010) and subsequent examination was revealed that $36.7 \%$ of the kitten did not have proctective antibody level despite routine vaccinations at the ages of $8 ., 12$. and 16. weeks, probably due to MDA. According to a recent study, MDA can be interferred the primary vaccination and kittens failed to develop active immunity following recommended routine vaccination scheme untill nearly 20 . week (Jakel et al. 2012). Importance of serological examinations on the determination of invidual vaccination shedule was pointed out in the same study. Low titres of MDA do not always protective from natural infection, but they may still interfere the vaccination (Scott et al. 1970). Evalluation of best starting point for primary vaccination by $\mathrm{Ab}$ testing in individual kittens accepted as the best option but this method is generaly not preferring in field conditions.

In an experimental study, kittens were vaccinated with trivalane vaccine in 8 and 12 . weeks and kept isolated from field conditions for a next tree years. After that, virulent field virus inoculated but clinical symtoms were not observed (Gore et al. 2006). In an another study, vaccinated cats were found to be immune at least for 6 years (Scott and Geissinger 1997). Considering stray cats lives nearly 6 years in the field conditions (Pontier 1993), it can be stated that recovered cats would be protected lifetime.

Presence of the FPLV and CPV infections have been known for a long time in Turkey, but there is no scientific report related history of the infection. Unowned cats and dogs live freely in the stray considitions. There is local barn and shelters but capacity is not adequate in Turkey. Vaccination applies are only limited with rabies for both species. Exposure risk for FLPV may be better understood considering environmental viral load and reciprocal transmissions.

Spatial distribution, social organisation and population dynamics are quite variable in cats (Lieberg et al. 2000). Studied locations is not close to each other in this study, detected variable ratios are confirm this. The another important point taking attention in this study is disparity between proportions and age. Young and 1-2 year old cats have higher values, this animals are obviously recovered ones. There is no information on mortality by reason of focused population. Owned cats are generally breeding as semi-indoor, by the way these cats are also under risk of infection via environmental viral load from clinical-subclinically infected cats and dogs together. Vaccination is stil the most effective preventive tool on control of the infection, with carefully considering MDA levels. Increase in shelter facilities for cats is also a neeed in the province like many place. 


\section{REFERENCES}

Alexander KA, Kat PW, Wayne RK, Fuller TK. Serological survey of selected canine pathogens among free-ranging jackals in Kenya. J Wildl Dis. 1994; 30:486-491.

Appel MJG, Scott FW, Carmichael LE. Isolation and immunisation studies of a canine parvolike virus from dogs with hemorrhagic enteritis. Vet Rec. 1979; 105:156-159.

Barker IK, Povey RC, Voigt DR. Response of mink, skunk, red fox and raccoon to inoculation with mink virus enteritis, feline panleukopenia and canine parvovirus and prevalence of antibody to parvovirus in wild carnivores in Ontario. Can J Comp Med. 1983; 47(2):188-197.

Bester MN, Skinner JD. The Marion Island cat programme. S Afr J Antarct Res. 1991; 20:14.

Blanco KL, Prendas J, Cortes R, Jimenez C, Dolz G. Seroprevalence of viral infections in domestic cats in Costa Rice. J Vet Med Sci. 2009; 71(5):661-663.

Carmichael LE. An annotated historical account of canine parvovirus. J Vet Med B, Infect Dis Vet Public Health 2005; 52(7-8):303-311.

Chalmers WSK, Truyen U, Greenwood NM, Baxendale W. Efficacy of feline panleukopenia vaccine to prevent infection with and isolate of CPV2b obtained from a cat. Vet Microbiol. 1999; 69:41-45.

Chang SF, Sgro JY, Parrish CR. Multiple amino acids in the capsid structure of canine parvovirus coordinately determine the canine host range and specific antigenic and hemagglutination properties. J Virol. 1992; 66(12):6858-7567.

Clegg SR, Coyne KP, Dawson S, Spibey N, Gaskell RM, Radford AD. Canine Parvovirus in asymptomatic feline carriers. Vet Microbiol. 2012; 157:78-85.

Davidson WR, Appel MJ, Doster GL, Baker OE, Brown JF. Diseases and parasites of red foxes, gray foxes and coyotes from commercial sources selling to fox-chasing enclosures. J Wildl Dis. 1992; 28:581-589.

Decaro N, Buonavoglia D, Desario C, Amorisco F, Colaianni ML, Parisi A, Terio V, Elia G, Lucente MS, Cavalli A, Martella V, Buonavoglia C. Characterisation of canine parvovirus strains isolated from cats with feline panleukopenia. Res Vet Sci. 2010; 89(2):275-278.

Gore TC, Lakshmanan N, Williams JR, Jirjis FF, Chester ST, Duncan KL, Coyne MJ, Lum MA, Sterner FJ. Three-year duration of immunity in cats following vaccination against feline rhinotacheitis virus, feline calicivirus, and feline panleukopenia virus. Vet Ther. 2006; 7(3):213-222.

Goyal SM, Mech LD, Rademacher RA, Khan MA, Seal US. Antibodies against canine parvovirus in wolves of Minnesota: a serological study from 1975 through 1985. J Am Vet Med Assoc. 1986; 189:1092-1094.

Hoffmann A, Schönborn E, Mergel A, Cußler K. Pharmakovigilanzreport Tierimpfstoffe: Analyse der im Jahr 2008 und 2009 im PaulEhrlich-Institut eingegangenen Meldungen. DTB1. 2010; 6:766-775.

Howell PG. An evaluation of the biological control of the feral cat Felis Catus (Linnaeus, 1758). Acta Zool Fenn. 1984; 172:111-113.

Ikeda Y, Mochizuki M, Naito R, Nakamura K, Miyazawa T, Mikami T, Takahashi E. Predominance of canine parvovirus (CPV) in unvaccinated cat populations and emergence of new antigenic types of CPVs in cats. Virology 2000; 278(1):13-19.

Ikeda Y, Nakamura K, Miyazawa T, Tohya Y, Takahashi E, Mochizuki M. Feline Host Range of Canine Parvovirus: Recent emergence of New antigenic types in cats. Emerg Infect Dis. 2002; 8(4):341-346.

Jakel V, Cussler K, Hanschmann KM, Truyen U, König M, Kamphuis E, Duchow K. Vaccination against Feline Panleukopenia: Implications from a field study in kitten. BMC Vet Res. 2012; 8:62.

Johnson RH. Isolation of a virus from a condition stimulating feline panleucopaenia in a leopard. Vet Rec. 1964; 76:1008-1012.

Koptopoulos G, Papadopoulos O, Papnastastasopoulo M, Cornwell HJC. Presence of antibodies cross-reacting with canine parvovirus in the sera of dogs from Greece. Vet Rec. 1986; 118(12):332-333.

Legeay Y. Le point sur les maladies infectieuses felines. ENV Nantes. J Nantaises Pathol Feline 1988, 1-14.

Lickey ALA, Kennedy M, Patton S, Ramsay EC. Serologic survey of domestic felids in the Peten region of Guatemala. J Zoo Wildl Med. 2005; 36:121-123.

Lieberg O, Sandell M, Pontier D, Natoli E. Density, spatial organisation and reproductive tactics in the domestic cat and other felids. In The domestic cat: the biology of its behaviour, (2nd edn (ed. Turner, D.C., Bateson, P.), pp 119-147, Cambride University Pres, 2000.

Macpherson LW. Feline enteritis virus- its transmission to mink under natural and experimental conditions. Can J Comp Med Vet Sci. 1956; 20(6):197-202.

Martyn JC, Davidson BE, Studdert MJ. Nucleotide sequence of feline panleukopenia virus: comparision wih canine parvovirus 
identifies host-specific differences. J Gen Virol. 1990; 71:2747-2753.

Mochizuki M, Horiuchi M, Hiragi $H$, San Gabriel MC, Yasuda N, Uno T. Isolation of caine parvovirus from a cat manifesting clinical signs of feline panleukopenia. J Clin Microbiol. 1996; 34(9):2101-2105.

Muz D, Oguzoglu TC, Timurkan MO, Akın H. Characterisation of the partial VP2 gene region of canine parvoviruses in domestic cats from Turkey. Virus Genes 2012; 44:301-308.

Nakamura K, Ikeda Y, Miyazawa T, Nguyen NT, Duong DD, Le KH, Vo SD, Phan LV, Mikami T, Takahashi E. Comparision of prevalance of feline herpesvirus type 1 , calicivirus and parvovirus infections in domestic and leopard cats in Vietnam. J Vet Med Sci. 1999; 61(12):1313-1315.

Nakamura K, Ikeda Y, Miyazawa T, Tohya Y, Takahashi E, Mochizuki M. Characterisation of cross-reactivity of virus neutralising antibodies induced by feline panleukopenia virus and canine parvoviruses. Res Vet Sci. 2001; 71(3):219-222.

Parrish CR. Mapping specific functions in the capsid structure of canine parvovirus and feline panleukopenia virus using infectious plasmid clones. Virology 1991; 183(1):195205.

Pontier, D. Analyse des traits d'histoire de vie chez les mammiferes. In: Memoire d'habilitation a diriger les recherches. France: Universite Lyon I, 1993.

Reif JS. Seasonality, natality and herd immunity in feline panleukopenia. Am. J. Epidemiol. 1976; 103:81-87.

Scott FW, Csiza CK, Gillespie JH. Maternally derived immunity to feline panleukopenia. J Am Vet Med Assoc. 1970; 156(4):439-453.

Scott FW, Geissinger C. Duration of immunity in cats vaccinated with an inactivated feline panleucopenia, herpesvirus and calicivirus vaccine. Feline Pract. 1997; 25:12-19.

Steinel A, Munson L, Van Vuuren M, Truyen U. Genetic characterization of feline parvovirus sequences from various carnivores. Gen Virol. 2000; 81:345-350.

Steinel A, Parrish CR, Bloom ME, Truyen U. Parvovirus infections in wild carnivores. J Wildl Dis. 2001; 37(3):594-607.

Studdert MJ, Kelly CM, Harrigan KE. Isolation of panleukopenia virus from lions. Vet Rec. 1973; 93:156-159.

Truyen U, Geissler K, Parrish CR, Hermanns W, Siegl G. No evidence for a role of modified live virus vaccines in the emergence of canine parvovirus. J Gen Virol. 1998; 79:1153-1158.

Truyen U, Parrish CR. Canine and feline host ranges of canine parvovirus ans feline panleukopenia virus. Distinct host cell tropisms of each virus in vitro and in vivo. J Virol. 1992; 66:5399-5408.

Truyen U. Emergence and recent avolution of canine parvovirus. Vet Microbiol. 1999; 69:204-208.

Truyen U. Evolution of canine parvovirus. A need for new vaccines? Vet Microbiol. 2006; 117(1):9-13.

Van Rensburg PJJ, Skinner JD, Van Aarde RJ. Effects of feline panleukopenia on the population characteristics of feral cats on Marion Island. J Appl Ecol. 1987; 24:63-73.

Veijaleinen P. A serological survey of enteric parvovirus infections in Finnish fur-bearing animals. Acta Vet Scand. 1986; 27:159-171.

Verge J, Christofoni N. La gastroenterite infectieuse des chats; est-elle due a un virus filtrable? Comptes Rendus des Sciences del Societe de Biologic et de ses filiales. 1928; 99:312.

Waller EF. Infectious gastroenteritis in racoons (Procyon lotor). J Am Vet Med Assoc. 1940; 96:266-268. 